\title{
Think it through first: questions to consider in writing a successful grant application
}

\author{
Owen J. Arthurs
}

Received: 25 February 2014 / Accepted: 12 May 2014

(C) The Author(s) 2014. This article is published with open access at Springerlink.com

\begin{abstract}
Writing a good grant application is a skill that can be rehearsed in the same way as writing a research paper or performing a scientific presentation to a lay audience. An overview of grant writing is provided here, with particular focus on the consideration and preparation required for each step.
\end{abstract}

Keywords Reseach funding · Paediatric radiology · Grant writing $\cdot$ National Institute for Health Research

\section{Outline and approach}

The ability to present a project's unique selling points succinctly, comprehensively and accurately is crucial to its success, but this can take a lot of practice. Allow plenty of time for the process of careful planning, ideas, hypothesis evaluation, discussion with colleagues, and several rounds of improvement and evolution to tailor the grant to the point of submission.

Before starting to write, consider the following key questions:

(1) Why is my project important and how is it different from others?

(2) What resources do I need?

(3) What type of grant do I need?

(4) Who can provide this type of funding?

(5) Why should they fund me?

\section{O. J. Arthurs $(\square)$}

Department of Radiology,

Great Ormond Street Hospital for Children NHS Foundation Trust,

Great Ormond Street, London, UK WC1N 3JH

e-mail: owen.arthurs@gosh.nhs.uk
Don't invent a project to fit a funding stream ("chasing the money"), but instead try to use your scientific and clinical knowledge to outline your project and proposal, and then find money to fund your vision rather than the other way around. When grant writing is difficult, try to verbalise your ideas and then write down your exact words, using this as a starting point for your writing.

After a project idea has been formulated, the required resources often determine the type of grant that is required. Several types of grants are available, including small project grants (for equipment, imaging costs), personal fellowships (for salary costs, sometimes including project costs), project grants (for a combination of salary and project costs) and programme grants (for comprehensive project costs and salary for several staff members). Check which funding body offers to fund which type of project, because most grant streams are quite specific about what they will and will not fund, both in terms of subject matter as well as resources (equipment or staff costs). Before starting, check directly with a funding organisation as to whether your proposal is suitable. If necessary, they may be able to point you towards a more appropriate funding stream.

If you have never applied for a grant, it may be best to start small. For instance several local groups, smaller charities, UK Royal Colleges, etc., offer start-up funding (which is also called small project grants, seed funding, or junior grants). There may be small grants available specific to your career grade, such as start-up grants for clinical lecturers or young academics within 5 or 10 years of completing their doctorate. These form a useful platform from which to gain pilot data, which can then be synthesised into a larger grant application. Getting a small grant is in itself an accomplishment that indicates potential, and is viewed favourably when applying for further funding. Read some general advice about grant writing [1-5] before finding out what might be available [6-12]. Consider the experiences of someone who already 
holds that particular type of grant [13] and whether there is local advice available from your own trust or support network $[14,15]$.

\section{The 3 Ps}

Grants are widely believed to focus around the three Ps - person, project and place. The person leading the project needs to have a strong curriculum vitae $(\mathrm{CV})$ or background and clear potential to succeed, and to be applying appropriately for their career stage and aspirations. The project should be novel, with high scientific merit and with clear aims and objectives as well as a realistic timeframe. It should address a fundamentally important research question (or takes steps towards this). The place should be an institution that has a strong track record in research, with the appropriate expertise, recognised supervisors/trainers and facilities. Many projects include an element of training, whether specific methodological aspects or generic research skills, and so it should be clear what new skills you will learn and that the senior members of your team are in a position to provide this. The project and training environment should be able to provide a valuable research experience.

\section{Key components (the $5 \mathrm{Ws}$ and the $\mathrm{H}$ )}

Funding bodies are looking to fund good-quality research, from researchers who will deliver on time, which represents good value for money (not necessarily cheap), and will have a wide scope outside the immediate research community. This is the what, where, when (why now?), how, who (why me?) and why approach. Whilst a funding body may require that your grant request be presented in a particular format, most grant applications adhere to the outline that follows (Table 1).

Summary: a succinct outline of your proposal

This is akin to the "elevator pitch" to outline your unique selling point. Imagine you and your hospital director or National Health Service chief executive stepped into the lift on the ground floor together and you had $90 \mathrm{~s}$ to get your point across. This type of "selling yourself" may not come naturally and may need several rounds of practice. Verbalising your proposal helps to iron out inconsistencies. You will also need a lay summary version of your proposal for a nonscientific audience.
The case for need: contextualise and quantify the problem

What is the question that I am addressing? Why is this project needed? What previous literature is available? How important, or how big, is the problem? What is being done by other groups? What type of study would be required in an ideal world to address this issue (the "best design" approach)? If your proposal were successfully funded and successful in answering its objectives, what would that mean in a wider context? What is needed to bring this project to a wider audience?

The aim of this project, in context

What is the expected outcome, and what is the expected impact? Individual projects rarely stand alone and should be portrayed within the wider context of your institution, career intensions, and scientific community. Weaker grants are more likely to be funded if the institution or researcher is particularly strong, and strong scientific applications may fail when there is perceived to be limited potential.

Methodology

The methodology section gives a skeleton or framework of the task and the resources required. How will potential sources of scientific bias be dealt with? It should also include rigorous statistical analysis and an estimation of the power of the study - e.g., how many participants will be needed to reach a conclusion with $\mathrm{x} \%$ confidence? This may be the first time that you have thought about involving a statistician, but doing so could help with much more than a sample size, including study objectives and design, analyses and outcome. It is often at this stage that other relevant team members become necessary, including clinical trialists, epidemiologists, health economists and qualitative researchers.

\section{Pilot data}

It is difficult to justify funding a theoretical problem but much easier to convince someone when you have tested your theories and demonstrated "proof of principle". Whereas a feasibility study answers the question "can this study be done?" a pilot study is a miniature version of the whole study to test whether all the components can all work together (recruitment, test, follow-up, etc.), and it is designed to iron out the logistical issues.

\section{Budget}

Financing your project appropriately is essential. You need to consider the people who will be needed, as well 
Table 1 Sample grant outline (modelled on NIHR RfPB outline)

\begin{tabular}{|c|c|c|}
\hline Section & What is required & Things to think about \\
\hline Research details & Generic details of host organisation, etc. & \\
\hline Research title & $\begin{array}{l}\text { Descriptive yet concise } \\
\text { State if pilot/feasibility study }\end{array}$ & $\begin{array}{l}\text { Keywords, and how to phrase the title } \\
\text { It should be clearly within the funding scope }\end{array}$ \\
\hline Lead applicant details & Your details & Who is the most appropriate person to lead the project? \\
\hline Lead applicant CV & 2-page summary CV & This should make it clear that you are the appropriate applicant \\
\hline Co-applicants & $\begin{array}{l}\text { The appropriate senior, junior and } \\
\text { multidisciplinary team }\end{array}$ & $\begin{array}{l}\text { Consider who will be providing a service for the project, and who } \\
\text { will be directly involved in the data. Grants are stronger when } \\
\text { statisticians, health economists, etc., are named as co-applicants }\end{array}$ \\
\hline Research \& development office & Who is hosting the project? & Usually the NHS organisation or affiliated university \\
\hline History of the application & $\begin{array}{l}\text { Have you submitted this to the } \\
\text { funding stream before? }\end{array}$ & How many attempts are allowed? \\
\hline Case for support point 1 & $\begin{array}{l}\text { Aims and objectives } \\
\text { Scientific summary } \\
\text { Lay summary } \\
\text { Background } \\
\text { Why is this research needed now? }\end{array}$ & $\begin{array}{l}\text { What is your research question and null hypothesis? } \\
\text { Outline the problem, research question, methodology and } \\
\text { expected impact. Summarise without jargon or difficult words } \\
\text { The background should be punchy, with reasons why the research } \\
\text { is necessary, highlighting the difficulties encountered by } \\
\text { yourself or others }\end{array}$ \\
\hline Case for support point 2 & Research plan and methodology & $\begin{array}{l}\text { Outline the entire study, including design, setting, sample size, } \\
\text { intervention, data collection, analysis and outcomes. Think } \\
\text { about feasibility, bias, and how much work is involved. How to } \\
\text { tackle potential problems? }\end{array}$ \\
\hline Case for support point 3 & Dissemination, outputs and expertise & $\begin{array}{l}\text { How are you going to publicise (not just publish) your data? } \\
\text { Think about Web sites and other social media, patient support } \\
\text { groups, targeted conferences and workshops }\end{array}$ \\
\hline Specific requirements & e.g., patient and public involvement & $\begin{array}{l}\text { These are specific to an individual funding body's particular } \\
\text { grant scheme, so find out as much as possible before you start }\end{array}$ \\
\hline Management and governance & $\begin{array}{l}\text { Who will oversee the project to make } \\
\text { sure it runs ethically, and on time? }\end{array}$ & $\begin{array}{l}\text { What might the project milestones be? } \\
\text { What are the key ethical issues in the project? }\end{array}$ \\
\hline Intellectual property & $\begin{array}{l}\text { Is there a new IP expected, or might your } \\
\text { findings conflict with pre-existing IP? }\end{array}$ & $\begin{array}{l}\text { IP is expensive to investigate, and so you should think about } \\
\text { pre-existing IP or asking for funding to copyright new IP. } \\
\text { Think about who would own the IP }\end{array}$ \\
\hline Finances & Budget your project & $\begin{array}{l}\text { How many of what equipment or staff do I need, over what time } \\
\text { period? Value for money is more important than absolute } \\
\text { figures - but each grant has a maximum limit }\end{array}$ \\
\hline Suggested reviewers & $\begin{array}{l}\text { Who might be experts in this field who } \\
\text { would give good objective feedback? }\end{array}$ & You should approach these people in advance to ask them \\
\hline Supporting documentation / appendix & $\begin{array}{l}\text { You may need to include images, diagrams, } \\
\text { etc., that do not fit elsewhere in the } \\
\text { application }\end{array}$ & \\
\hline
\end{tabular}

Adapted with permission from [1]

$C V$ curriculum vitae, $I P$ intellectual property, NHS National Health Service, NIHR National Institute for Health Research, RfPB Research for Patient Benefit

as materials, equipment, space and time. Try to justify your inclusion of everyone and everything, including who is accountable for what. Funding bodies look for a mix of personnel with the right expertise and skills and a strong track record. Under-estimating or exaggerating the team skills or cost of your project is inappropriate; you must ensure that everything you need to make the project succeed is either included in the grant or is clearly funded from elsewhere. If there are potential intellectual property issues, either new or conflicting, this needs to be carefully considered, and any necessary investigation needs to be included in the budget. Discussing your project early with your finance manager or equivalent is extremely useful.

\section{Generic guidance around grant writing}

Find or talk to someone who has written a similar grant, particularly for this funding body.

Several funding bodies publish their remit or scope, and your project must fit neatly within their portfolio of studies. They may also publish lists of current successful grants, where 
you may be able to identify both helpful colleagues and potential conflicts of interest, and they may publish examples of successful grants ("sample grants") to help you.

\section{Read the terms and conditions carefully}

All grant applications come with several pages of assistance regarding how to complete the document. Funders take a dim view of those who stray outside their guidance, either by asking for inappropriate items or by not conforming to the desired funding stream (remit or scope). Most funders expect to be telephoned for advice regarding the application process, and whilst they will not give specific advice, they can steer you in a helpful direction. Explicit requirements (e.g., patient involvement) should be clearly outlined and not included as an afterthought.

\section{Keep the writing clear and the reader engaged}

You should try to clearly and concisely outline the problem, in the context of the current scientific literature, and demonstrate a clear need for your research. The style of writing can influence reader engagement. Appropriate punctuation, use of headings, boldface or italics for emphasis, and bullet points can help keep the reader (and author) focussed. Avoid technical jargon and unusual acronyms, but do include buzzwords.

\section{If at first you don't succeed, try again and again}

Many funding bodies publish success rates, which may be as low as $5-10 \%$. When a grant application is turned down, try to get feedback as to why it wasn't successful. Did you anticipate the potential problems in the grant that the funding body identified? Did you show that you had recognised these and thought how they might be dealt with, if encountered? Some funding bodies provide limited feedback and allow a limited number of repeated attempts at each stage - it is worth knowing how many attempts you have in advance of your first one. Several larger grant applications are now a two-stage process: an initial outline stage, and then a full application. It is strongly advised that you have written the full application by the time the outline deadline has arrived.

\section{Success! The next steps}

There are several requirements for getting a project up and running other than successful funding. These include a sponsor (the organisation accountable for the research), ethical approval from a recognised body (to protect research participants), local research and development approval or permission, local research networks, as well as other regulatory approvals (e.g., clinical trials, medicines) and honorary contracts for those involved. Applying for these may be just as time-consuming (if not more so) than the actual grant application process and should ideally be undertaken in parallel. Getting the grant is just the beginning of your research journey, and whilst you are enjoying the research, bear in mind that all grants are finite, with a clear end date, and you will need to justify the use of resources.

\section{Conclusion}

Although the grant writing process may seem daunting, help is widely available at each step, from conception through to submission. Your local research and development team, fellow scientists (especially those who sit on grant review panels), funding bodies and several Web sites are useful sources of guidance regarding where to start, and they might offer to review your proposals and give helpful feedback. The earlier you start, the more detailed feedback you will get, and the more time you have to respond to that feedback, so the better your application will be.

Acknowledgements The author is funded by a National Institute for Health Research (NIHR) Clinician Scientist Fellowship. This article was informed by a master class delivered by the team at Research Design Service South Central (RDS SC), funded by the National Institute for Health Research (NIHR). The views expressed are those of the author and not necessarily those of the NHS, the NIHR or the Department of Health.

\section{Conflicts of interest None}

Open Access This article is distributed under the terms of the Creative Commons Attribution License which permits any use, distribution, and reproduction in any medium, provided the original author(s) and the source are credited.

\section{References}

1. Research Design Service, South Central (2012) Masterclass in writing RfPB grant application. http://www.rds-sc.nihr.ac.uk/wp-content/ uploads/2012/04/Masterclass-03-Feb-2012.pdf. Accessed 06 Dec 2013

2. Research Design Service, South Central (2012) Statistical considerations for grant applications. http:/www.rds-sc.nihr.ac.uk/rds-masterclasses/ statistical-considerations-for-grant-applications. Accessed 06 Dec 2013

3. National Institute of Neurological Disorders and Stroke (2011) How to write a research project grant application. http://www.ninds.nih. gov/funding/write_grant_doc.htm. Accessed 06 Dec 2013

4. National Institute of Neurological Disorders and Stroke (2011) Common mistakes in NIH applications. http://www.ninds.nih.gov/ funding/grantwriting mistakes.htm. Accessed 06 Dec 2013

5. Economic and Social Research Council (2013) How to write a good research grant proposal. http://www.esrc.ac.uk/funding-andguidance/applicants/how-to.aspx. Accessed 06 Dec 2013 
6. Whitby E (2014) Funding resources for junior pediatric radiology clinical scientists: where should they look? Pediatr Radiol. doi: 10.1007/s00247-014-3046-5.

7. European Society of Radiology (2013) Grants \& fellowships. http:// www.myesr.org/cms/website.php?id=/en/education training/radiology trainees_forum/grants_fellowships.htm. Accessed $0 \overline{6}$ Dec 2013

8. The Royal College of Radiologists (2013) Academic radiology and research. http://www.rcr.ac.uk/content.aspx?PageID=1860. Accessed 06 Dec 2013

9. Medical Research Council (2013) Funding opportunities http://www. mrc.ac.uk/Fundingopportunities/Grants/index.htm. Accessed 06 Dec 2013

10. Wellcome Trust (2013) http://www.wellcome.ac.uk/Funding. Accessed 06 Dec 2013
11. National Institute for Health Research (2013) http://www.nihr.ac.uk/ research/Pages/default.aspx. Accessed 06 Dec 2013

12. National Institutes of Health (2013) http://grants.nih.gov/grants/oer. htm. Accessed 06 Dec 2013

13. Bruton A (2013) Annie Bruton's Blog. NIHR research fellowships: 5 tips for how to get one. http://anniebruton.wordpress.com/2013/09/ 09/nihr-research-fellowships/. Accessed 06 Dec 2013

14. The Leeds Teaching Hospital NHS Trust (2013) How to write a grant application. http://www.leedsth.nhs.uk/academic/research-development information-for-researchers/research-proposal/how-to-write-a-grantapplication/. Accessed 06 Dec 2013

15. Burt J. Cambridge Centre for Health Services Research (2013) The (sort of) essential guide to writing a grant application. http://www. cchsr.iph.cam.ac.uk/1077. Accessed 06 Dec 2013 